\section{Brazilian Journal \\ of Chemical \\ Engineering}

\title{
DRYING KINETICS OF SOME BUILDING MATERIALS
}

\author{
A. Moropoulou, M. Karoglou, A. Giakoumaki, M.K. Krokida, \\ Z.B. Maroulis and G.D. Saravacos \\ National Technical University of Athens, 15780, Greece. \\ E-mail: mkrok@chemeng.ntua.gr \\ E-mail: margo@central.ntua.gr
}

(Received: October 20, 2004 ; Accepted: November 20, 2004)

\begin{abstract}
Moisture is one of the most deteriorating factors of buildings. The deteriorating effect of moisture occurs mainly during the drying phase, and not in the wetting phase. Appropriate parameters of the drying kinetics are required for the building materials. Environmental factors, such as air temperature, air humidity, and air velocity affect drying. An experimental air dryer of controlled drying air conditions was used to investigate the drying performance of 4 stone materials, 2 bricks and 7 plasters. Drying kinetics was examined at 4 air temperatures, 6 air humidities, and 3 air velocities. A first-order kinetics model was obtained, in which the drying time constant was a function of the drying conditions, and the equilibrium material moisture content was described by the Oswin equation. The parameters of the proposed model were found to be affected strongly by the material and the drying air conditions. The results obtained are very useful in selecting the appropriate plaster to protect existing historic buildings.

Keywords: Stones; Bricks; Plasters; Sorption Isotherms.
\end{abstract}

\section{INTRODUCTION}

Moisture is one of the most deteriorating factors of buildings. The masonry moisture content depends on hygroscopic equilibrium between buildings materials and environment (Albanesi, 1998), which is determined by the drying and wetting rate of masonry. So, the moisture content is not only determined by the water that is absorbed by the material, but also by the amount of water that is evaporated under favorable conditions, which is described by the drying process. Thus, the investigation of materials drying kinetics is very useful in understanding the effect of environmental conditions on the moist storage of building materials.

Moreover, most building materials are hygroscopic, which means that they absorb water vapour from the environment until equilibrium conditions are achieved. This behaviour can be described by the isotherm sorption curves over a humidity range between 0 and ca 95\% relative humidity (Kuenzel, 1995).

Many moisture transfer models have been used to describe the drying process of porous materials in the food and chemical industry (Maroulis \& Saravacos 2003). In this case, a first order drying kinetic model is used to describe heat and mass transfer phenomena. The drying time constant depends on both material and drying air properties, as it is the phenomenological property representative of several transport phenomena. The effect of air temperature, relative humidity and air velocity on drying time constant of building materials has been studied partially (Jayamaha et al, 1996; Derdour et al 2000).

The objective of this work is to investigate the drying kinetics and water sorption and desorption isotherms of some building materials. More specifically, the aim of this work was to study the effect of some drying conditions on the progress of the drying process. The air temperature was $20^{\circ}$ -

*To whom correspondence should be addressed 
$45^{\circ} \mathrm{C}$, the relative humidity $10-80 \%$ and the air velocity varied from 1 to $8 \mathrm{~m} / \mathrm{s}$.

\section{MATHEMATICAL MODEL}

The drying time constant can be defined using the so-called thin-layer equation. It is assumed that the material layer is thin enough or the air velocity is high so that the conditions of the drying air (humidity, temperature) are kept constant throughout the material. The drying time constant depends on both material and air properties as it is the phenomenological property representative of several transport phenomena. So, it is a function of material moisture content, as well as air humidity, temperature, and velocity. The mathematical model used to calculate the drying time constant from experimental data has been discussed analytically by various researchers (Saravacos \& Maroulis 2001; Maroulis \& Saravacos 2003) and it is summarized in Table 1.

\section{Table 1: Parameters estimation}

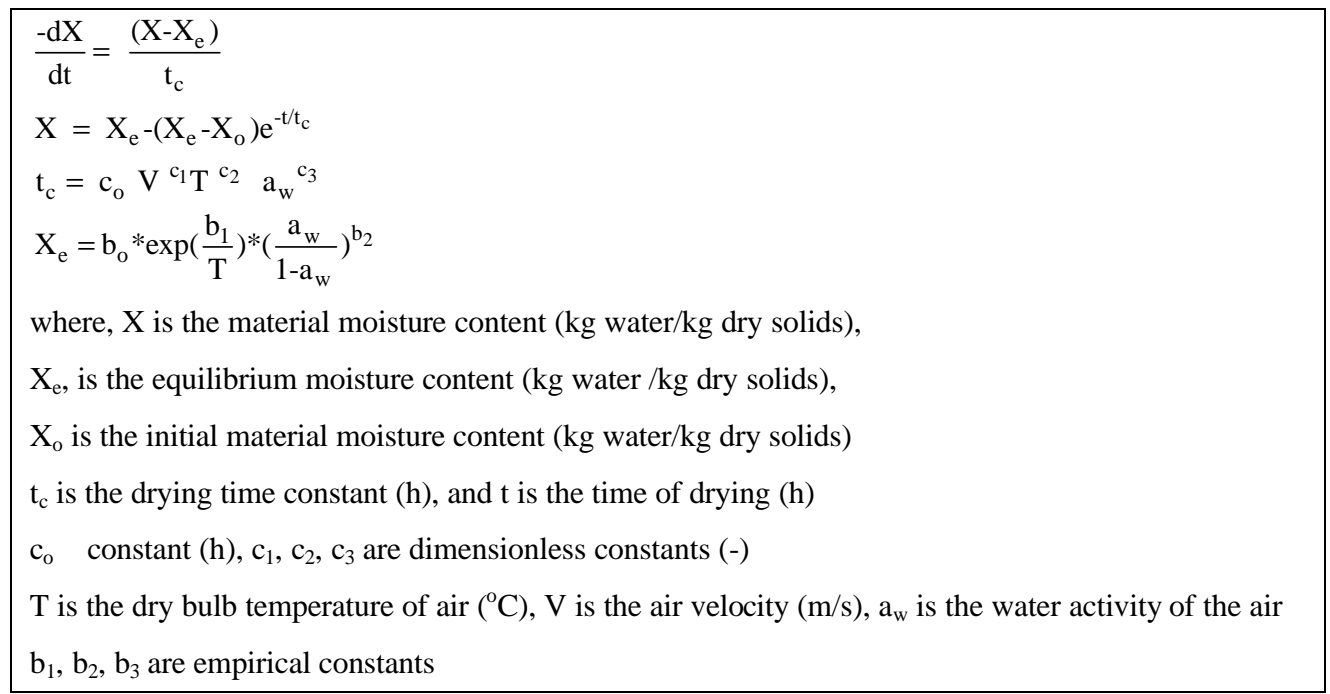

\section{MATERIALS AND METHODS}

Three categories of building materials were studied: bricks, plasters and stones. For each category various materials were selected, having different microstructrural characteristics. Especially, the following plasters were selected: pre-mixed mortars suitable for masonries suffering from rising damp phenomena, traditional plasters from a historic building, and a cement-based product commonly used in modern and historic constructions. The premixed mortars were prepared according to manufactures specifications. The material characteristics are summarized in Table 2.

A water sorption analysis (CISORP, CI Electronics Ltd), was used in order to estimate the water sorption-desorption isotherms of the samples. Water uptake and release was determined gravimetrically, i.e. by weighing the sample during the process. The samples weighed about $0.5 \mathrm{~g}$. The isotherms were estimated for three operating temperatures $\left(15^{\circ} \mathrm{C}, 25^{\circ} \mathrm{C}\right.$, and $\left.35^{\circ} \mathrm{C}\right)$, while the relative humidity changed from $0-90 \%$, using a 10 scale step, at ambient pressure. Data were recorded and saved automatically during the experiments.

Experiments to determine the influence of process variables on the drying kinetics were performed in a convective air dryer. The variables taken into consideration were the air temperature, air humidity and air velocity. The drying experiments were carried out with sample size of $3 \times 3 \times 3 \mathrm{~cm}$ for each material, at four levels of air-temperature $\left(20^{\circ}\right.$, $30^{\circ}$ and $35^{\circ} \mathrm{C}$ and $40^{\circ} \mathrm{C}$ ), three levels of air velocity $(1,3$ and $8 \mathrm{~m} / \mathrm{s})$ and 6 levels of relative humidity of the air $(30,40,50,60,70$ and $80 \%)$. Before the start of the experiment the samples were saturated with water through imbibition in distilled water, according to Italian recommendation Normal/20-85. 
Table 2: Materials

\begin{tabular}{|c|c|c|}
\hline Code & Materials & Comments \\
\hline \multicolumn{3}{|r|}{ Bricks } \\
\hline BRI & $\begin{array}{l}\text { Country: } \\
\text { Italy }\end{array}$ & Hand-made clay brick \\
\hline BRM & $\begin{array}{l}\text { Country: } \\
\text { Greece }\end{array}$ & Hand-made clay brick \\
\hline \multicolumn{3}{|r|}{ Plasters } \\
\hline PEM & Pre-mixed & $\begin{array}{l}\text { Suitable for masonries suffering from rising damp } \\
\text { phenomena/ binder: hydraulic lime }\end{array}$ \\
\hline PMP & Pre-mixed & $\begin{array}{l}\text { Suitable for masonries suffering from rising damp } \\
\text { phenomena/ binder: aerial lime }\end{array}$ \\
\hline PRL & Premixed & $\begin{array}{l}\text { Suitable for masonries suffering from rising damp } \\
\text { phenomena/ binder: cement }\end{array}$ \\
\hline PTI & Premixed & Cement -based mortar \\
\hline PTR & Premixed & $\begin{array}{l}\text { Suitable for masonries suffering from rising damp } \\
\text { phenomena/ binder: cement }\end{array}$ \\
\hline PZN1 & Traditional & $\begin{array}{l}\text { From a neoclassical building (of 19th century) at Athens } \\
\text { City Center/ binder: aerial lime }\end{array}$ \\
\hline PZN2 & Traditional & $\begin{array}{l}\text { From a neoclassical building (of 19th century) at Athens } \\
\text { City Center / binder: aerial lime }\end{array}$ \\
\hline \multicolumn{3}{|r|}{ Stones } \\
\hline SCY & Cyprus & Quarry sandstone \\
\hline SRH & Rhodes & Quarry sandstone \\
\hline SRY & $\begin{array}{l}\text { Rethimno } \\
\text { Yellow }\end{array}$ & Quarry sandstone \\
\hline SWR & $\begin{array}{l}\text { Rethimno } \\
\text { White }\end{array}$ & Quarry sandstone \\
\hline
\end{tabular}

\section{RESULTS AND DISCUSSION}

The mathematical model of Table 1 was fitted to the experimental data and the results of parameter estimation are summarized in Table 3. Each set of parameters corresponds to a different building material. The corresponding values of residual sum of squares are also given in Table 3. The main results are summarized in Figures 1 through 4.

The equilibrium material moisture content is strongly affected by temperature and humidity of surrounding air. Thus, the equilibrium material moisture content is higher at lower air temperature and at higher humidity levels. The equilibrium material moisture content of various materials is presented in Figure 1. It must be noted that most of the examined materials showed a significant hysteresis between sorption and desorption isotherm curves (Figure 2).

The experimental and calculated results of the model for the drying of a building material are given in Figure 3. In this Figure, the effect of various parameters is shown. As expected, there is an acceleration of the drying process due to the increase of the air velocity of the drying air from 1 to $8 \mathrm{~m} / \mathrm{sec}$. The effect of air humidity is also considered very important, which makes the drying rate decrease as the air humidity increases from 30 to $70 \%$. The effect of air relative humidity and air velocity on the drying time constant is presented in Figure 4 for most of the examined building materials. The drying time constant values decrease with air velocity and increase with air humidity of all the examined materials, with a range varying between various materials depending on the type of the examined material. 
Table 3: Estimated Parameters

\begin{tabular}{|l|c|c|c|c|c|c|c|r|r|}
\hline Materials & $\mathbf{c}_{\mathbf{0}}$ & $\mathbf{c}_{\mathbf{1}}$ & $\mathbf{c}_{\mathbf{2}}$ & $\mathbf{c}_{\mathbf{3}}$ & $\mathbf{S}_{\mathbf{k}}$ & $\mathbf{b}_{\mathbf{0}}$ & $\mathbf{b}_{\mathbf{1}}$ & $\mathbf{b}_{\mathbf{2}}$ & $\mathbf{S}_{\mathbf{X}}$ \\
\hline BRI & 1.80 & & & 0.89 & 0.037 & $2.39 \mathrm{E}-02$ & 1.16 & 0.30 & 1.7 \\
BRM & 1.10 & & & 0.89 & 0.010 & $3.10 \mathrm{E}-02$ & 0.73 & 0.41 & 0.4 \\
PEM & 1.16 & & & 1.01 & 0.055 & $4.55 \mathrm{E}-07$ & 3.80 & 0.66 & 0.5 \\
PMP & 0.91 & & & 0.84 & 0.005 & $3.19 \mathrm{E}-05$ & 2.49 & 0.45 & 0.1 \\
PRL & 1.21 & & & 0.85 & 0.011 & $3.53 \mathrm{E}-02$ & 0.57 & 0.51 & 0.2 \\
PTI & 1.26 & & & 0.78 & 0.016 & $1.46 \mathrm{E}-05$ & 2.33 & 0.71 & 0.0 \\
PTR & 1.73 & \multirow{2}{*}{0.8} & 0 & 0.83 & 0.117 & $5.40 \mathrm{E}-03$ & 1.31 & 0.35 & 2.1 \\
PZN1 & 1.11 & & & 0.67 & 0.015 & $1.44 \mathrm{E}-04$ & 2.55 & 0.38 & 17.7 \\
PZN2 & 0.99 & & & 0.55 & 0.021 & $1.69 \mathrm{E}-02$ & 1.10 & 0.44 & 12.3 \\
SCY & 0.92 & & & 0.47 & 0.005 & $2.00 \mathrm{E}-06$ & 3.60 & 0.44 & 4.5 \\
SRH & 0.77 & & & 0.87 & 0.003 & $7.17 \mathrm{E}-06$ & 3.85 & 0.31 & 239.2 \\
SRY & 1.14 & & & 0.85 & 0.009 & $8.61 \mathrm{E}-07$ & 3.79 & 1.03 & 13.2 \\
SWR & 0.89 & & & 0.73 & 0.007 & $2.05 \mathrm{E}-06$ & 3.58 & 0.62 & 3.3 \\
\hline
\end{tabular}

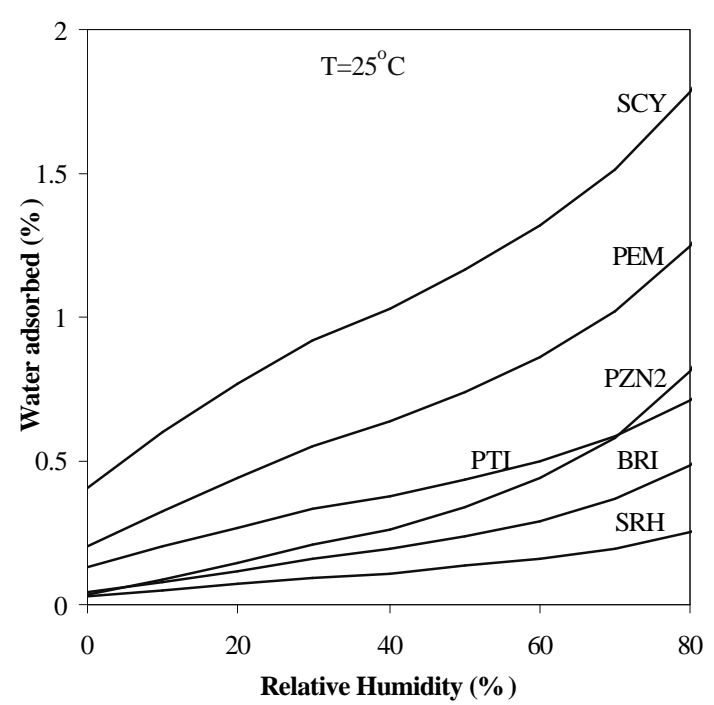

Figure 1: Isotherms of some building materials at $\mathrm{T}=20^{\circ} \mathrm{C}$.

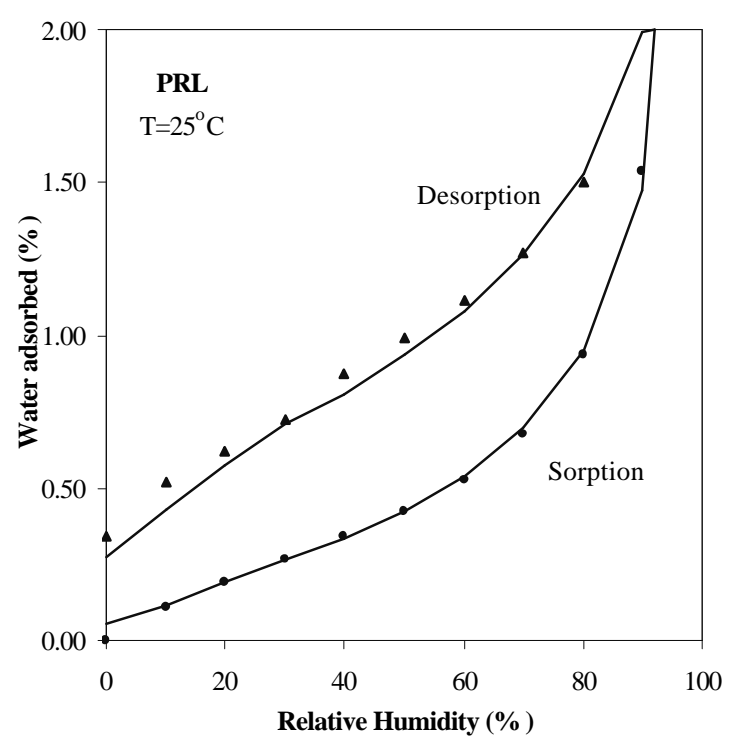

Figure 2: Sorption and desorption isotherms of PRL (plaster) at $\mathrm{T}=20^{\circ} \mathrm{C}$.

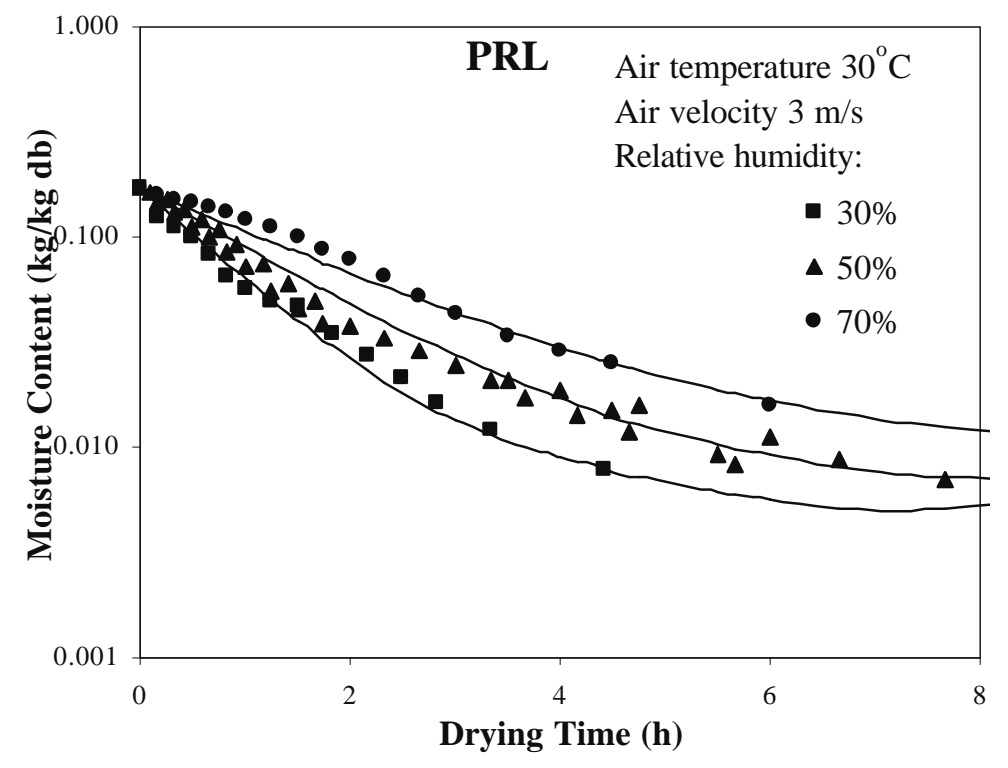




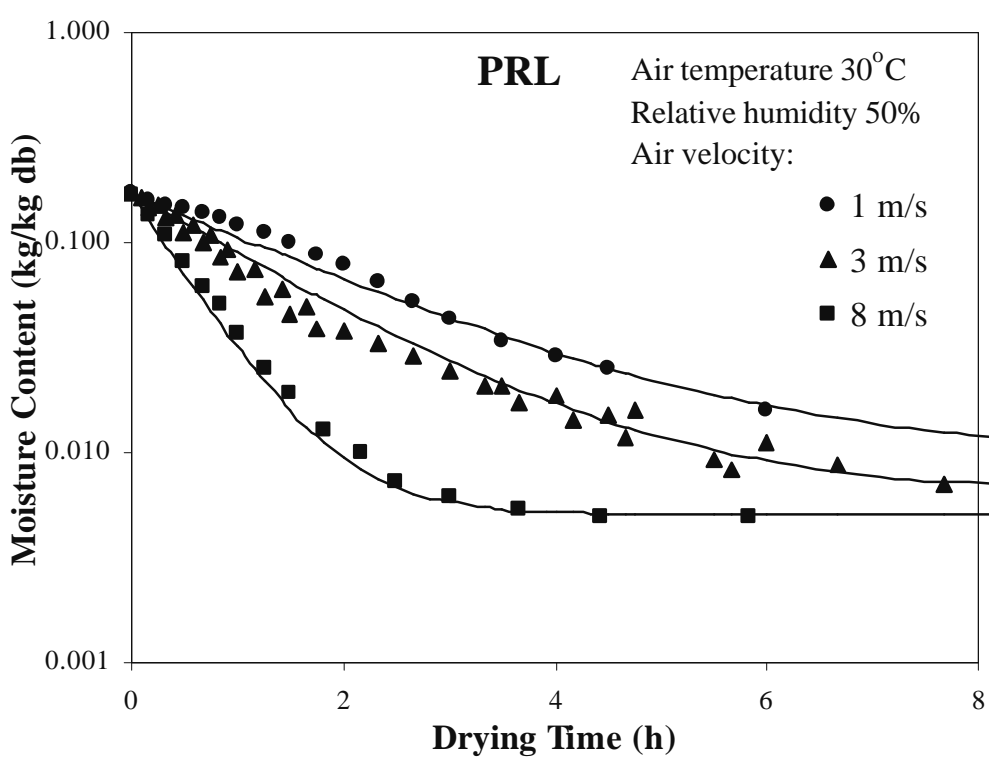

Figure 3: Effect of air relative humidity and air velocity at drying kinetics of PRL (plaster).
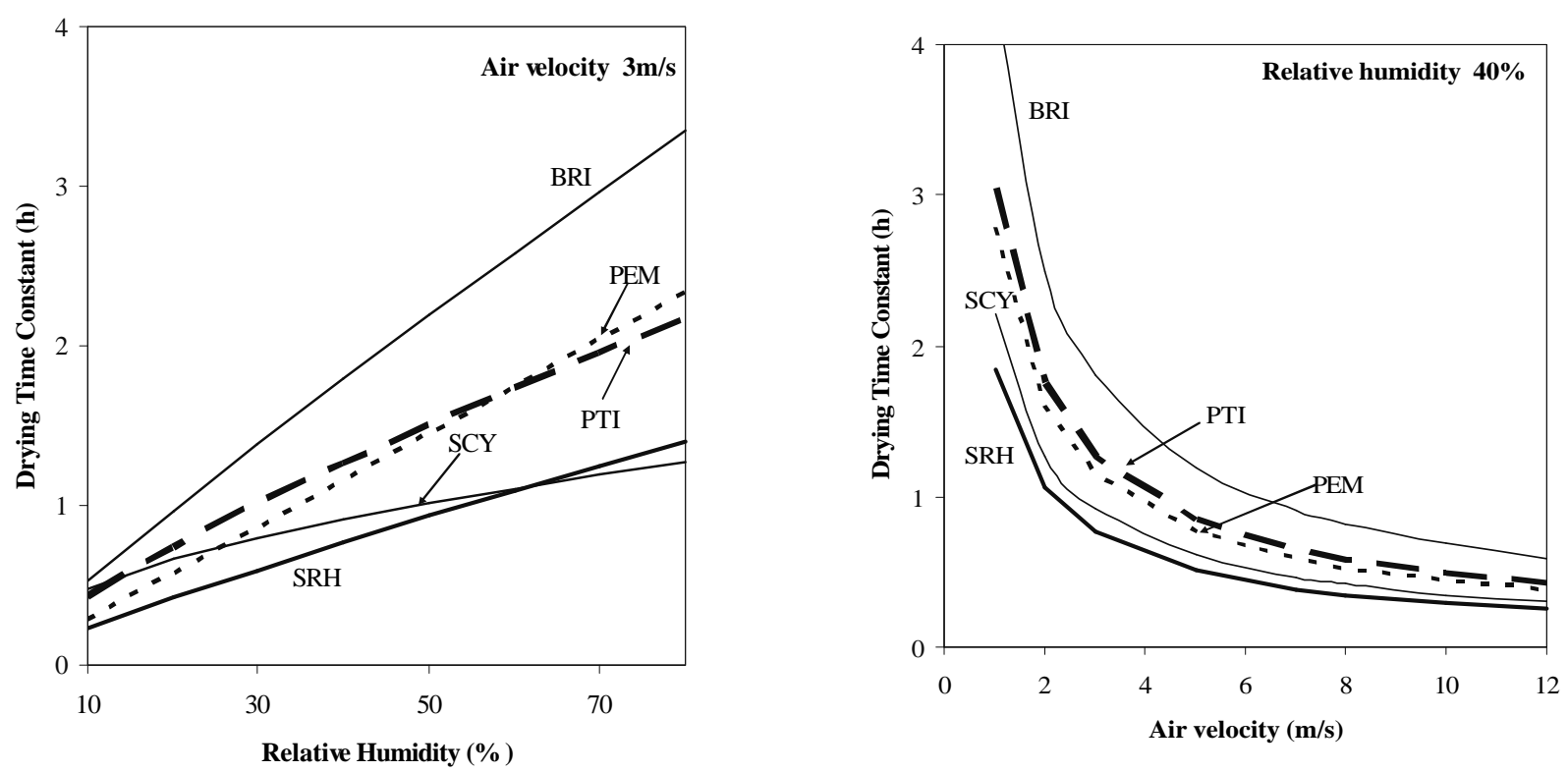

Figure 4: Effect of air relative humidity and air velocity on drying time constants for various building materials.

\section{CONCLUSIONS}

The effect of drying conditions, such as air temperature, relative humidity and velocity on the progress of the drying process of various building materials was investigated. A drying model was developed, incorporating the effect of the above conditions on the drying process. The equilibrium material moisture content of the examined materials was also found based on an Oswin model. The drying model predicted successfully the drying of several building materials.

\section{NOMENCLATURE}

$\begin{array}{cl}\mathrm{a}_{\mathrm{w}} & \text { Water activity of the air } \\ \mathrm{b}_{1} & \text { Empirical constant } \\ \mathrm{b}_{2} & \text { Empirical constant } \\ \mathrm{b}_{3} & \text { Empirical constant }\end{array}$

$(\mathrm{kg} / \mathrm{kg} \mathrm{db} \%)$ 
$\mathrm{c}_{\mathrm{o}}$

$\mathrm{c}_{1}, \mathrm{c}_{2}, \mathrm{c}_{3}$

$\mathrm{S}_{\mathrm{k}}$

$\mathrm{S}_{\mathrm{Xe}}$

$\mathrm{T}$

$\mathrm{t}$

$\mathrm{t}_{\mathrm{c}}$

V

$\mathrm{X}$

$\mathrm{X}_{\mathrm{e}}$

$X_{\text {o }}$
Constant

Empirical constants

Residual sum of squares

Residual sum of squares

Dry bulb temperature of air

Time of drying

Drying time constant

Air velocity

Material moisture content

Material equilibrium

moisture content

Initial material moisture content (h)

$(-)$

$(\mathrm{kg} / \mathrm{kg} \mathrm{db} \%)$

$(\mathrm{kg} / \mathrm{kg} \mathrm{db} \%)$

$\left({ }^{\circ} \mathrm{C}\right)$

(h)

(h)

$(\mathrm{m} / \mathrm{s})$

( $\mathrm{kg}$ water $/ \mathrm{kg}$ dry solids)

(kg water $/ \mathrm{kg}$ dry solids)

( $\mathrm{kg}$ water $/ \mathrm{kg}$ dry solids)

\section{REFERENCES}

Albanesi, G., (1986), Trattamento delle murature umide, Report di ricerca interno Euro resine spa.

Kuenzel, H. M., Simultaneous Heat and Moisture Transport in Building Components; one-and twodimensional calculation using simple parameters, IRB-Verlag, ISBN 3-8167-4103, (1995).

Maroulis, Z.B., \& Saravacos, G., Food Process Design, 1st ed., Marcel Dekker, New York, (2003).

Saravacos, G. \& Maroulis, Z.B., Transport Properties of Foods, 1st ed., Marcel Dekker, New York, (2001). 